Osoba i doświadczenie mistyczne (4) „Filozofia Chrześcijańska” 16 (2019), s. 73-85

\author{
JADWIGA CLEA MORENO-SZYPOWSKA \\ Polska Akademia Nauk \\ Instytut Badań Literackich
}

\title{
Mistyka życia versus mistyka śmierci. Porównanie wizji św. Teresy od Jezusa z filozoficznym ujęciem Giorgia Agambena
}

1 [To wam oznajmiamy], co było od początku,
cośmy ustyszeli o Słowie życia,
co ujrzeliśmy własnymi oczami,
na co patrzyliśmy
i czego dotykaty nasze ręce -
2 bo życie objawiło się.
Myśmy je widzieli,
o nim świadczymy
i głosimy wam życie wieczne,
które było w Ojcu,
a nam zostało objawione -
3 oznajmiamy wam,
cośmy ujrzeli i ustyszeli, abyście $i$ wy mieli wspótuczestnictwo z nami ${ }^{1}$.

(„Prolog”, 1 List św. Jana, Biblia)

Zadaniem z pozoru zbyt śmiałym jest porównanie kanonicznego tekstu rozkwitu mistyki, jakim jest Zamek wewnętrzny czyli Mieszkania ${ }^{2}$ św. Teresy od Jezusa (ur. 1515 - zm. 1582), z nieortodoksyjnym tekstem Język i śmierć.

11 J 1,1-4, wszystkie cytaty z Pisma Świętego za: Biblia Tysiąclecia, http://biblia.deon.pl/ [dostęp: 27.09.2019]. 2009. 
Seminarium o miejscu negatywności $i^{3}$ Giorgia Agambena (ur. 1942), który, wedle mojej opinii, zaliczyć można do współczesnej mistyki. Dzieło to, niestety, nie zostało jeszcze przełożone na język polski, stąd też korzystam z hiszpańskiego wydania, co ma walory, gdyż zarówno język włoski, jak i hiszpański należą do rodziny języków romańskich, a Agamben często posługuje się etymologią dla udowodnienia swoich twierdzeń i aspekt językowy jest dlań nader istotny. Warto nadmienić, że sam świetnie zna język hiszpański, i można przypuszczać, że owo thumaczenie było z nim uzgadniane.
Długa jest droga,
Po tym padole;
Pełne trudu mieszkanie,
Ciężkie wygnanie.
Och, marzenie uwielbione!
Wyprowadź mnie stąd!
Wzdychajac za Twym widzeniem,
Pragnę umrzećt.

Wygnani z raju, miejsca, które Bóg stworzył dla człowieka, musimy podjąć trud powrotu do naszego mieszkania, by w nim zaznać szczęśliwości miłowania i bycia miłowanymi. Pomogą nam w tym wskazówki św. Teresy oraz rozważania Agambena. Raj to wedle włoskiego filozofa kraina, gdzie nie ma ani bólu, ani śmierci, gdyż człowiek pozbawiony jest tam skazy natury ${ }^{5}$. Twierdzeniem, że raj, w którym człowiek nie umiera, jest jego właściwym miejscem istnienia, Agamben przeciwstawia się myśli jednego ze swoich mistrzów, jakim był Martin Heidegger, dla którego Dasein (pol. 'Jestestwo'6), czyli to „bycie-ku-śmierci” (niem. Sein-zum-Tode ${ }^{7}$ jest podstawą odróżniającą człowieka od innych istot.

Może dziwić zestawienie tych autorów, tak od siebie odległych, nie tylko czasowo, (dzieli ich ponad czterysta lat), lecz także kulturowo. Święta Teresa reprezentuje kulturę życia, bo chociaż barok uważa się za epokę celebrującą

${ }^{3}$ G. Agamben, El lenguaje y la muerte. Un seminario sobre el lugar de la negatividad, thum. T. Segovia, Valencia 2003.

4 „Carrera muy larga/ Es la de este suelo;/ Morada penosa,/ Muy duro destierro./ ¡Oh sueño adorado!/ ¡Sácame de aquí!/ Ansiosa de verte,/ Deseo morir”. - Fragment wiersza Ayes del destierro św. Teresy od Jezusa w tłumaczeniu własnym. Wiersz w oryginale w: Teresa od Jezusa, Poezje. Poesías, Kraków 2015, s. 42. Tom wierszy opatrzony jest tekstami w oryginale oraz w przekładzie Marty Szafrańskiej-Brandt. Jednakże odchodzę od owego tłumaczenia, gdyż, aczkolwiek dobrze brzmiące po polsku, nie oddaje rozpatrywanych przeze mnie pojęć.

5 Zob. G. Agamben, El lenguaje y la muerte, dz. cyt., s. 156.

6 Zob. M. Heidegger, Bycie i czas, tłum. B. Baran, Warszawa 1994.

7 Zob. M. Heidegger, §52, „Das alltägliche Sein zum Ende und der volle existenziale Begriff des Todes” w: M. Heidegger, Sein und Zeit, Tübingen 2006, s. 255-260. 
śmierć, to śmierć ta nakierowana jest na zmartwychwstanie, czyli życie. Agamben natomiast jest przedstawicielem kultury śmierci, pozornie wbrew współczesnej cywilizacji, w której akcentuje się znaczenie niepodważalnych praw człowieka do szczęśliwego życia. Mimo tej zasadniczej różnicy oboje podążają za Słowem, zawierającym w sobie samo bycie, które się unaocznia w obliczu śmierci. Słowo staje się środkiem dojścia do wyznaczonego miejsca, jakim jest prawdziwe mieszkanie człowieka, który - póki co - znajduje się, wedle obu pisarzy, na wygnaniu.

Mroczne jest życie,

Gorzkie do skrajności;

Nie żyje dusza, która

Jest daleka od Ciebie.

Och, słodkie moje dobro,

Jaka nieszczęśliwa jestem!

Wzdychając za Twym widzeniem,

Pragnę umrzećs.

Zarówno dla św. Teresy, jak i Agambena człowiek jest stworzeniem mającym dwie natury: jedną żyjącą podług wskazań świata zewnętrznego i zdeterminowaną przez procesy biologiczne, z których najważniejszym jest umieranie, oraz drugą, u św. Teresy duchową, mającą duszę i ducha, które stanowią jedność ${ }^{9}$, choć są od siebie rozdzielone, zaś u Agambena kulturową ${ }^{10}$, czyli ukształtowaną przez język i mowę. Te ostatnie, również, jak dusza i duch, stanowią jedność, lecz są istotnie od siebie rozróżnione. Słowo pisane bądź wypowiedziane, będące narzędziem komunikacji, nie tylko autorów z czytelnikami, lecz także Boga ze stworzeniem, stanowi punkt wyjścia dla obu myślicieli. Obaj autorzy odczuwają potrzebę objaśnienia lektorom okoliczności powstania swoich tekstów.

Święta Teresa tworzy Zamek wewnętrzny w „roku 1577, w karmelitańskim klasztorze św. Józefa w Toledo""11. Wiadomo, że w tym czasie jej inne dzieło,

8 „Lúgubre es la vida,/ Amarga en extremo;/ Que no vive el alma/ Que está de ti lejos./ ¡Oh dulce bien mío,/ Que soy infeliz!/ Ansiosa de verte,/ Deseo morir". - Fragment wiersza Ayes del destierro św. Teresy od Jezusa w tłumaczeniu własnym. Wiersz w oryginale w: Teresa od Jezusa, Poezje. Poesías, dz. cyt., s. 42.

9 Zob. Teresa od Jezusa, Siódme mieszkanie, w: Teresa od Jezusa, Zamek wewnętrzny czyli Mieszkania, dz. cyt., s. 266.

${ }^{10}$ Zob. G. Agamben, El lenguaje y la muerte, dz. cyt., s. 136.

${ }^{11}$ Zob. Teresa od Jezusa, Prolog, w:. Teresa od Jezusa, Zamek wewnętrzny czyli Mieszkania, dz. cyt., s. 28. 
Księga życia, jest w rękach inkwizycji ${ }^{12}$. Dlatego ojciec Gracjan ${ }^{13}$, przełożony św. Teresy, poleca jej, by napisała nową książkę, w której zawrze swoje wcześniejsze rozmyślania. Posłuszna zabiera się do pracy z zamiarem przyczynienia się do powiększenia chwały Boga i dla pożytku zakonnic, które, dzięki jej pismom, będą mogły się doskonalić w wierze. Giorgio Agamben objaśnia w notce poprzedzającej wstęp, że książka Język $i$ śmierć jest wynikiem rozważań omówionych podczas seminarium, które miało miejsce od zimy 1979 aż do lata 1980. Brali w nim udział także: Massimo De Carolis, Giuseppe Russo, Antonella Moscati i Noemi Plastino ${ }^{14}$. Uznać można więc tę pracę za dzieło zbiorowe, jak podkreśla sam filozof. Materiały w nim zawarte były dyskutowane podczas ośmiu spotkań. Ciekawe jest pewne podobieństwo wynikające z samej konstrukcji omawianych dzieł: św. Teresa buduje swoją książkę na wizji siedmiu mieszkań zamku, a więc przestrzeni, Agamben zaś rozkłada swoje rozważania na osiem jednostek czasowych. I choć jedna stawia nacisk na przestrzeń, a drugi na czas, to oboje podkreślają wagę podwalin, na których budują swoje myśli.

Mimo wielu różnic, wynikających głównie z osobowości omawianych autorów, znaleźć można także pewne podobieństwa, które to dały motyw do ich porównania. Są one również natury formalnej: zauważmy, że oboje czują potrzebę objaśnienia okoliczności powstania swoich dzieł i wynika z nich jasno, że opisane przemyślenia oparte zostały na czymś wcześniej przeżytym. Święta Teresa od Jezusa spisuje ponownie to, czego doznała poprzednio; specyfiką tekstów mistycznych jest, że są one świadectwem doświadczeń osoby piszącej, a samo przelanie na papier stanowi etap końcowy nadprzyrodzonego zdarzenia. Dlatego w mistyce często pojawia się zaimek dzierżawczy „mój” w odniesieniu do Boga, zauważmy, że zawsze jest mowa o „moim Bogu". Nie chodzi tu bynajmniej o przywłaszczenie sobie Wiekuistego, lecz o podkreślenie, że wizja, którą starają się wyrazić słowami, właśnie im się w takiej formie objawiła. Mistycy odczuwają potrzebę, czy też konieczność, podzielenia się z innymi łaską, którą zostali obdarzeni. Mimo iż są to dzieła pisane często $\mathrm{w}$ pierwszej osobie liczby pojedynczej i czynnik podmiotu jest nader istotny, to jednak ich przedmiotem oraz głównym „bohaterem” zawsze jest Wszechmocny, bez którego nic w ogóle nie istnieje i którego wybór, padając na nich, stał się impulsem do stworzenia tekstu. Agamben także spisuje treści omówione poprzednio $w$ zakończonym seminarium i, podobnie jak św. Teresa, która trzyma się z ostrożnością uznanej doktryny Kościoła, włoski filozof stara się wiernie je przekazać. Oboje chcą dać świadectwo czemuś, co

12 Zob. W. Ciak, Wprowadzenie, w: Teresa od Jezusa, Zamek wewnętrzny czyli Mieszkania, dz. cyt., s. 9.

13 Jerónimo Gracián Dantisco (1545-1614) - zakonnik karmelitów bosych i hiszpański pisarz; ojciec duchowy św. Teresy od Jezusa. Wnuk polskiego dyplomaty Jana Dantyszka (1485-1548).

${ }^{14}$ G. Agamben, El lenguaje y la muerte, dz. cyt., s. 5. 
już miało miejsce, i czują się zobowiązani nakazem wierności nie tylko względem siebie, lecz, co ważniejsze, względem innych: Kościoła lub seminarzystów. Tekst Agambena nie jest pisany w toku rozważań, lecz jest spisywany na podstawie doświadczeń $\mathrm{z}$ danego okresu, dotyczących jego oraz innych osób. Tu pojawia się istotna różnica: św. Teresa mówi o swoich, najbardziej intymnych przejściach, często nadprzyrodzonych, których zrozumienie graniczy z ludzką możliwością; Agamben relacjonuje akademicki epizod, który mógłby być dostępny dla większego grona, bo uczestnictwo w nim uwarunkowane jest raczej zajmowaną pozycją społeczną. Nie sposób przyswoić duchowego testamentu św. Teresy od Jezusa, nie mając wiary, a filozofia Agambena, mimo całej swej złożoności - gdyż opiera się ona, na jakże trudnej, myśli Georga Wilhelma Hegla oraz Martina Heideggera - przyswojenia jako takiego nie wymaga. By móc, w duchu św. Teresy, pojąć jej teksty, nie możemy się zatrzymywać na ich niewątpliwym pięknie i traktować wyłącznie jako dyskurs literacki. Szczególny jest ich walor nie tyle dydaktyczny, ile objawieniowy, są one bowiem poświadczeniem istnienia Boga. Paradoksalny wydaje się fakt, że nauka traktuje mistykę jako z gruntu niepewną, nawet jako rodzaj mistyfika$\mathrm{cji}^{15}$, i zarzuca jej całkowitą subiektywność. W rzeczywistości, jeśli potraktujemy wydarzenie mistyczne jako przeżycie konkretnej osoby, zrozumiemy, że mamy do czynienia z doświadczeniem empirycznym, a takowe jest podstawą niejednego naukowego twierdzenia. Nie wchodząc w zawiły świat prawdziwości, chcę tylko podkreślić, że mistyczna pewność, to pewność przeżyta, rzecz jasna, wewnętrznie, której należy się dosłownie wiarygodność.

Omawiane teksty, zarówno myślicielki z Ávila, jak i rzymskiego filozofa, mają na celu objawić pewną prawdę znaną tylko im. Uznać je więc można za apokalipsy, które ujawniają przykrytą rzeczywistość, dotyczącą Boskiej Istoty lub ludzkiego istnienia $\mathrm{i}$ jego wymiaru językowego. $\mathrm{W}$ obu przypadkach zawiera się cel dydaktyczny, potwierdzony przez fakt, że adresatem jest konkretna wspólnota odbiorców. Zważywszy na przedsięwziętą misję odsłonięcia prawdy, można potraktować te przekazy jako posłannictwo. Święta Teresa dąży do wyznaczenia drogi dojścia do doskonałości oraz dojrzałości duchowej, ukoronowanej mistycznymi zaślubinami z Królem zamku. Zewnętrznym przejawem tejże dojrzałości ma być miłość do bliźnich. Agamben chce pokazać potrzebę powrotu do stanu dziecka, a więc człowieka niewładającego jeszcze językiem, czyli nieskażonego skrytymi przesądami, gdyż tylko tak będzie mógł on od nowa zjednoczyć się z Innymi w zgodzie i pokoju. Włoski filozof ponadto postrzega dziecko jako istotę pozbawioną woli i głosu ${ }^{16}$, a więc

${ }^{15}$ Etymologiczny rodowód wyrazu „mistyka” $i$ „mistyfikacja” odsyła do znaczenia greckiego słowa mystikós ('tajemnica'). Semantyczny związek tych pojęć był zapewne przyczyną kwestionowania czasem w środowiskach naukowych wartości poznawczej doświadczenia mistycznego.

${ }^{16}$ Zob. G. Agamben, El lenguaje y la muerte, dz. cyt., s. 167. 
we wspólnocie składającej się z takich członków nie są możliwe spory, brak bowiem pragnień, które dałyby do nich powód. Powrót do utraconego domu-raju, dojrzałości dla jednej, a dziecięctwa dla drugiego, to temat zajmujący zarówno św. Teresę, jak też Agambena. Myśl ich łączy zdanie św. Pawła: „Bracia, nie bądźcie dziećmi w swoim myśleniu, lecz bądźcie jak niemowlęta, gdy chodzi o rzeczy złe. W myślach waszych bądźcie dojrzali!" ${ }^{17}$. Warto zwrócić uwagę, że niemowlę, to istota pozbawiona mowy, co świetnie wpisuje się w myśl Agambena. Apostoł stawia jako wzór zjednoczenie cech niemowlęctwa (ufności, braku uprzedzeń) z dojrzałością myśli, co wydawać się może sprzeczne bądź niemożliwe do zrealizowania, gdyż każda forma intelektualna oparta jest na pewnych przesłankach.

Wracając do przerwanego wątku, należy podkreślić, że oboje, kreśląc ścieżkę powrotu do domu, przedstawiają go jako siedzibę właściwą dla człowieka, a więc ostateczny cel wędrówki. Mimo częstych u św. Teresy upomnień, że trzeba iść dalej, owa dal jest wewnętrzna i znajduje się w Agambenowskiej głębi, tworzącej podwaliny podzamcza. Agamben, objaśniając konieczność oparcia się na fundamencie, precyzuje, że chodzi mu o metafizyczne rozumienie tego pojęcia, które odnosi się do tego, co jest w głębi samego bycia ${ }^{18}$. Dla hiszpańskiej mistyczki oczywistym fundamentem jest wiara, na której wznosi się widoczny zamek miłości do Boga. Agamben, który nieraz odwołuje się do filozoficznego pojęcia „głębi”, pokazuje jednak, że współczesna mistyka śmierci opiera się na nieistniejącej nicości, z której to wynika wszelka niedojrzałość ludzka oraz niezdefiniowanie tak charakterystyczne dla współczesnego społeczeństwa ${ }^{19}$, grzeszącego nieokreśleniem, do którego dobrze stosują się słowa z Apokalipsy św. Jana:

A tak, skoro jesteś letni i ani gorący, ani zimny, chcę cię wyrzucić z mych ust ${ }^{20}$.

Ciekawe jest, że Agamben zarzuca mistyce brak fundamentów, czemu daje wyraz na samym początku książki: „myśleć mistycznie, czyli bez podstaw” ${ }^{21}$. Podstawą wszelkiej wiary jest Bóg, w świecie, który Go „uśmiercił”, mistyka straciła podwaliny i jej katedra się chwieje. Pusta świątynia, z której wygnano Ojca, nie może już być schronieniem dla cudzoziemców, wdów i sierot.

171 Kor 14,20 .

${ }_{18}$ Zob. G. Agamben, El lenguaje y la muerte, dz. cyt., s. 11.

19 Zob. G. Agamben, Idea prozy, tłum. E. Górniak Morgan, Warszawa 2018, s. 101-106.

${ }^{20}$ Ap 3,16.

${ }^{21}$ Zob. G. Agamben, El lenguaje y la muerte, dz. cyt., s. 10 (tłumaczenie własne). 
Jakże smutne jest Boże,

Życie bez Ciebie!

Wzdychając za Twym widzeniem,

Pragnę umrzećc 22 .

Święta Teresa słusznie zauważa, że bez Niego życie staje się smutne, a co gorsza, nieznośne w swoim ciągłym przerażeniu, gdyż jako sieroty utraciliśmy Obrońcę na tym łez padole. Mimo że jesteśmy skazani, póki co, na przebywanie tutaj, to jednak nie jesteśmy stąd. Raz wypędzeni z raju, wciąż odczuwamy nostalgię, czyli tęsknotę za domem, chęć powrotu do niego, o której mówi Agamben i której świadectwem jest propozycja św. Teresy, by wniknąć w samego siebie, gdyż tam znajduje się kokon czy też gniazdo dla duszy, której obrazem jest raz motyl, raz ptak. I choć mieszkanie jest już w nas, to trzeba wciąż do niego powracać, aby nie uczynić jak rabin Izaak, syn Jekla z Krakowa, bohater Opowieści chasydów Martina Bubera ${ }^{23}$, który udaje się do Pragi w poszukiwaniu skarbu, znajdującego się w rzeczywistości w jego własnym domu. Podobni do archeologów, powinniśmy kopać w swojej duszy i znalezione komnaty przemierzać, żeby dojść do tej królewskiej, w której znajduje się sam Bóg, największy klejnot. W tym celu jednak wciąż należy pielęgnować ów zamek oraz, co ważniejsze, dbać o jego fundamenty, na których cała budowla się opiera. Jedynym sposobem, wedle Świętej, jest dogłębne i ciągłe poznawanie samego siebie, do czego również skłaniają rozważania filozofa. Wędrówka rozpoczyna się od chęci wydostania się z przedzamcza, w którym panuje karnawałowy zgiełk i, co za tym idzie, odwrócenie wszelkich wartości. Następnie należy podjąć kroki w kierunku wnętrza rezydencji, a jest nimi odpowiednio przysposobiona modlitwa. Dopiero wtedy otwierają się bramy i zadaniem duszy w pierwszych trzech mieszkaniach jest właśnie poznanie samej siebie, zgodnie z delficką maksymą. Dzięki temu w dalszej podróży będzie ona mogła okiełznać własne skłonności wynikające z pragnień zmysłów czy władz, które pośrednio nią rządzą. Dotarłszy raz do takiej znajomości siebie samej, gdzie wola potrafi narzucić się innym chęciom, wkraczamy do czwartej sali. Tutaj dusza poddana zostaje próbie miłości i musi sprostać wielkim cierpieniom, płynącym nie tylko z zewnątrz, w postaci szykan ze strony bliskiego środowiska, lecz także $\mathrm{z}$ wnętrza, a więc bólom fizycznym, otępiającym ciało i umysł. Jest to próg, który koniecznie trzeba przekroczyć, by móc kontynuować powrotną drogę do raju. Czwarte mieszkanie stanowi pewną formę inicjacji, jedynie zdolna dusza może przejść dalej do głębszego wtajemniczenia,

22 „¡Cuán triste es, Dios mío,/ La vida sin ti!/ Ansiosa de verte, / Deseo morir” - Fragment wiersza Ayes del destierro św. Teresy od Jezusa w tłumaczeniu własnym. Wiersz w oryginale w: Teresa od Jezusa, Poezje. Poesías, dz. cyt., s. 42.

${ }^{23}$ Zob. M. Buber, Opowieści chasydów, tłum. P. Hertz, Poznań 1986. 
pojawiającego się w piątym alkierzu. Tam zaczynają się zjawiska nadprzyrodzone, dusza, uporawszy się z rozumem, który uznać należy za potrzebną, lecz nie absolutną władzę, jest teraz w stanie je przyjąć, choć nie bez oczywistych obaw. Od tej pory dalsze wnikanie duszy w samą siebie oraz, tym samym, zbliżanie się do królewskiej siódmej komnaty, przepełnione będzie coraz intensywniejszymi i nadziemskimi doświadczeniami, ogromną radością i szczęściem z odczuwania Bożej bliskości, lecz także straszliwymi fizycznymi i duchowymi mękami, będącymi zapłatą za otrzymany dar. Owe przeszywające bóle - wyrażenie to należy traktować dosłownie, gdyż św. Teresa mówi, że dusza jest jakby przeszyta strzałą, co ją upodabnia do św. Sebastiana - to nie tylko cena, którą wybrani muszą ponieść, ale również kontynuacja próby, stanowiącej rodzaj duchowego ćwiczenia koniecznego dla osiągnięcia doskonałości, tak potrzebnej, by w szóstej komnacie stać się narzeczoną Oblubieńca, zaś w siódmej Jego żoną. Warto nadmienić, że każda forma miłości pociąga za sobą cierpienie, czego najlepszym przykładem jest figura Kupidyna, który aby zakochać w sobie wybraną parę, rani ją strzałą. Jeśli dusza czerpać będzie spokój z pewności zjednoczenia z Bogiem, umartwienia nie staną jej na przeszkodzie i będzie zdolna do wkroczenia do boskiej komnaty oraz przeżycia ekstazy, która wedle myśli niektórych współczesnych filozofów, w tym Giorgia Agambena i Maurice'a Blanchota, jest raną, przez którą to, co wewnętrzne, ujawnia się na zewnątrz ${ }^{24}$. Mowa była o bólach, które dusza przeżywa aż do samego końca, stąd też to współczesne rozumienie „ekstazy” jest nader trafne.

O mistycznym przeżyciu ekstazy mówi także Agamben, lecz w innym, aczkolwiek podobnym duchu jak św. Teresa. Opierając się na tradycyjnym rozumieniu „ekstazy” jako wyjścia z siebie, włoski filozof podkreśla niezbędność pozbycia się swoich cech indywidualnych, nawiązując do stworzonego przez siebie pojęcia bycia ,jakimkolwiek" 25 , jak dziecko, które dopiero co się kształtuje, i przez to upodobnienia się do bliźniego, dzięki czemu wszyscy stają się tacy sami. Pragnienie wyjścia z siebie związane jest z chęcią bycia tym Innym. Święta Teresa, podążając za słowami Jezusa: „«Ja jestem drogą i prawdą, i życiem [...]»" ${ }^{26}$ namawia do Jego naśladownictwa. Idzie ona o krok dalej niż Agamben, gdyż stając się podobni do Niego, przepełniamy się Bożym miłosierdziem, objawiającym się w nieprzerwanej miłości do bliźniego. Wierzy ona w to, co głosi wszelka mistyka chrześcijańska, iż poprzez

${ }^{24}$ Zob. E. Pino Estivill, La «cosa misma» del lenguaje en Giorgio Agamben. Una revisión del concepto de comunidad, „Romanica Olomucensia” Nr 26.1, 2014, s. 106, file:///C:/Users/Asus/AppData/Local/Temp/Dialnet-LaCosaMismaDelLenguajeEnGiorgioAgambenUnaRevisionD-4872611. pdf [dostęp: 27.01.2019].

${ }^{25}$ Zob. G. Agamben, Wspólnota która nadchodzi, tłum. S. Królak, Warszawa 2008, s. 7.

$26 \mathrm{~J} 14,6$. 
naśladownictwo Jezusa Chrystusa dokonuje się całkowitego przeobrażenia bytu, do tego stopnia, że istota przestaje w zupełności być sobą. Powrót Agambena jest cofnięciem się do etapu dzieciństwa, zaś powrót św. Teresy jest dojściem do etapu dojrzałości, jakim jest świętość. Święty Jan idealnie opisuje oba stany w Pierwszym Liście:

Umiłowani, obecnie jesteśmy dziećmi Bożymi, ale jeszcze się nie ujawniło, czym będziemy.

Wiemy, że gdy się objawi, będziemy do Niego podobni, bo ujrzymy Go takim, jakim jest.

Każdy zaś, kto pokłada w Nim tę nadzieję, uświęca się, podobnie jak On jest święty ${ }^{27}$.

By jednak do tego dotrzeć, dusza musi zjednoczyć swoją wolę z Bożą i przebywać w siódmej komnacie, będącej przedsionkiem nieba. Terminologia zamku daje możliwość wprowadzenia także takich terminów jak: Pan i niewolnik, które również się pojawiają u Agambena, posługującego się nimi w komentarzu do Femomenologii ducha Hegla. Oboje rozpatrują tę parę pojęć w kontekście kwestii woli i pragnienia. Będąc poddanymi Pana, spełniamy Jego pragnienia, co dla Świętej jest pozytywne. Nakłania ona do bycia niewolnikami Boga. Dla Agambena zniewolenie jest negatywne, jak cała jego mistyka śmierci. Absolutny suweren dzierży władzę nad poddanym i odczuwa radość z zabicia go. Prawo zadania śmierci jest zarezerwowane jedynie dla Boga ${ }^{28}$. U św. Teresy dusza, nawet niewolnika, ma wolną wolę, która może przejawić się w chęci uśmiercenia siebie, by być z Bogiem. U Agambena zaś wolna wola jest przywilejem wyłącznie Pana.

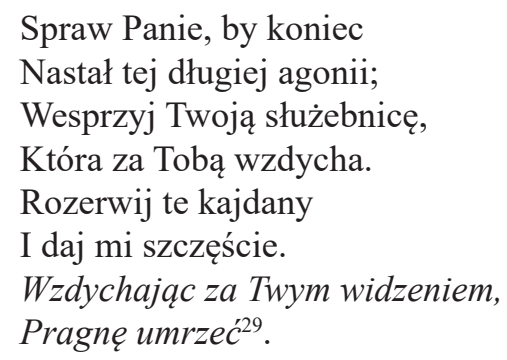

${ }^{27} 1 \mathrm{~J} 3,2-3$

${ }_{28}$ Zob. G Agamben, El lenguaje y la muerte, dz. cyt., s. 83-87.

${ }^{29}$ „Haz, Señor, que acabe/ Tan larga agonía;/ Socorre a tu sierva/ Que por ti suspira./ Rompe aquestos hierros/Y sea feliz./ Ansiosa de verte,/ Deseo morir". - Fragment wiersza Ayes del destierro 
Każdy z nas ma wewnętrzny głos, oddzielny od naszego własnego. W nim objawia się wola Pana, przybierająca postać milczącego głosu sumienia, o którym mówią oboje. Płynie on z wnętrza i strzeże przed obrażeniem Jego Majestatu, jak zwie Boga św. Teresa. Agamben widzi sumienie odmiennie, jest ono głosem Innego i wiąże się z elementem ekstatycznym, o którym była wcześniej mowa, kiedy ,ja” wychodzi z siebie i staje się tym Innym ${ }^{30}$. Pobrzmiewa tutaj złota zasada postępowania: „Wszystko więc, co byście chcieli, żeby wam ludzie czynili, i wy im czyńcie!”’31, będąca filarem etyki, o której niemało głosi włoski filozof, idąc za myślą Emmanuela Lévinasa ${ }^{32}$. Ten ostatni podkreśla, że w każdym spotkaniu z Innym twarz jego wyraża: „Nie zabijaj!”. Stanowczo twierdzi, że współczesna ontologia oraz teologia opierać się powinny na etyce, będącej główną dziedziną filozofii. Agamben wnikliwie analizuje ów milczący głos, który jest w człowieku i kieruje jego zachowaniem. Dla św. Teresy jest on po prostu boskim nakazem, dzięki któremu wie, jak podążać, by nie skrzywdzić swojego Oblubieńca. Ów milczący głos, będący dla obojga rodzajem boskiej mowy, poprzez którą Stwórca komunikuje się ze stworzeniem, jest najskrytszym znakiem Jego Istnienia oraz obrazem Jego hojności względem każdego $\mathrm{z}$ nas. Ponadto dla włoskiego filozofa w sumieniu wyraziście zaznacza się granica naszego języka. W języku zaś głos płynie $\mathrm{z}$ wewnętrznej mowy. Tak też pojawienie się mowy, wyrażonej poprzez bezdźwięczny głos, podważa cały konstrukt językowy, stanowiący dla Agambena szkielet człowieka. Choć włoski filozof nie chce wprost przyznać się do tego, iż ludzki umysł nie jest w stanie przeniknąć tego, że istnieć może bezdźwięczna mowa, to jednak, czytając jego pisma, odczuwa się tętniącą pewność istnienia Boga, niebędącego Heglowskim Absolutem, dającym się zawrzeć w ludzkim rozumie. Chcąc nie chcąc, Agambenowska negacja, której dowodem jest boska mowa, posługująca się milczeniem, jest pozytywnym objawieniem Boskiego Bytu, o jakim stara się pisać św. Teresa. Właśnie w tej niemożności opisania tego, co przeżyła, ukazuje się niezaprzeczalne istnienie Pana Wszechrzeczy. Jest akurat odwrotnie, niż się śniło filozofom: to zawieszenie ludzkich możliwości poznania jest najlepszym poświadczeniem boskiej ręki, kierującej ludzkim życiem. Jakże często prosi Święta o wstawiennictwo Ducha Świętego, by móc wyrazić swoje wizje. Jakże często uskarża się na nieadekwatność słów, niezdolnych do przekazania tego, co chce wyrazić. Niestety, póki ludzka istota nie włada boską mową, jedynym najbardziej dosłownym instrumentem,

św. Teresy od Jezusa w tłumaczeniu własnym. Wiersz w oryginale w: Teresa od Jezusa, Poezje. Poesías, dz. cyt., s. 48.

${ }^{30}$ Zob. Giorgio Agamben, El lenguaje y la muerte, dz. cyt., s. 75.

${ }_{31}$ Mt 7,12.

${ }^{32}$ Zob. E. Lévinas, Całość i nieskończoność: esej o zewnętrzności, tłum. M. Kowalska, Warszawa 1998. 
którym może się posłużyć, by oddać swoje relacje z Bogiem, jest milczenie. Dla św. Teresy milczenie jest afirmatywną formą komunikacji, zaś dla Agambena - absolutnej negacji. Jedna widzi w nim Słowo Życia, zgodnie z Ewangelią św. Jana:

Na początku było Słowo,

Słowo było u Boga,

i Bogiem było Słowo.

Ono było na początku u Boga.

Wszystko przez Nie się stało,

bez Niego nic się nie stało, co się stało.

W Nim było życie,

a życie było światłością ludzi,

a światłość w ciemności świeci

i ciemność jej nie ogarnęła ${ }^{33}$.

Drugi zaś „martwą literę”, w którą wkrada się śmierć, niebędąca bramą do Nieba, lecz murem Nicości, którego brak jest nie do przekroczenia. Jednakże owo milczenie staje się dla współczesnych myślicieli wejściem do wiecznych filozoficznych spekulacji, które biorą dla swojej własnej argumentacji tylko pierwszą część myśli św. Teresy:

Och dobra śmierci, ratuj mnie od trosk!

Twoje ciosy są słodkie, bo uwalniają duszę,

odrzucając, jakże ważną, jeśli nie najważniejszą, kontynuację:

Jakie szczęście, mój Oblubieńcze, być obok Ciebie!

Wzdychajac za Twym widzeniem,

Pragnę umrzeć ${ }^{34}$.

Zapytać więc można na koniec, czyżby człowiek współczesny, zakorzeniony w mistyce śmierci, nie stał się podobny do owego grzesznika z Psalmu 38 , który tak siebie określa:

${ }^{33} \mathrm{~J} 1,1-5$.

${ }^{34}, ¡$ ¡Oh muerte benigna,/ Socorre mis penas!/ Tus golpes son dulces,/ Que el alma libertan./ ¡Qué dicha, mi Amado,/ Estar junto a ti!/ Ansiosa de verte,/ Deseo morir". - Fragment wiersza Ayes del destierro św. Teresy od Jezusa w tłumaczeniu własnym. Wiersz w oryginale w: Teresa od Jezusa, Poezje. Poesías, dz. cyt., s. 42 i s. 44. 
A ja nie słyszę - jak głuchy;

i jestem jak niemy, co ust nie otwiera.

I stałem się jak człowiek, co nie słyszy;

i nie ma w ustach odpowiedzi ${ }^{35}$.

W świecie bez Boga bowiem, gdzie prawda staje się rzeczą prywatną, gdzie środek, jakim jest język, staje się ludzkim budulcem, gdzie obsesja samookreślenia ogarnęła wszystkie dziedziny, miejsce mistyki życia zajęła mistyka śmierci, ponieważ śmierć to jedyny ocalały ślad duchowego aspektu człowieka. Mimo to istota w obliczu nagiej śmierci - parafrazując Agambenowskie pojęcie „nagiego życia”- za którą nie stoi żadna nadzieja, może jedynie pozostać niema. Milczenie zostało jej odjęte, gdyż straciła mowę. Milczenie straciło zaś swój symboliczny wymiar, gdyż w obliczu pustki nicość już niczego nie wyraża. I zamiast dzwonów pobrzmiewają zewsząd słowa z Dziadów Adama Mickiewicza: „Ciemno wszędzie, głucho wszędzie, co to będzie, co to będzie?"36.

\title{
THE MYSTICISM OF LIFE VERSUS THE MYSTICISM OF DEATH \\ Comparison of the SAINT TERESA OF JeSUS \\ WITH THE PHILOSOPHICAL VIEW OF GIORGIO AGAMBEN
}

\begin{abstract}
Reading the text of the main representative of Spanish mysticism, which is Saint Teresa of Jesus, we can see similarities with the philosophical reflections of the modern thinker Giorgio Agamben. In both of them we find an analogous approach to the issues that concern them the most: for the mystic it is God, for Agamben, language. Poetic images used by Saint Teresa of Jesus, are transforming into the philosophical concepts used by Agamben. The thinking of both is similar, although the message is completely different. Filled with the "faith, hope and love" of Saint Teresa of Jesus wants to draw a path, a leading soul to God, a synonym for life, and Agamben, influenced by the thoughts of Hegel and Heidegger, outlines a situation in which a lost human being is in a cul-de-sac ending with terrifying death wall. Hence the mysticism of the sixteenth century can be called the mysticism of life, while philosophical considerations over the language of the twentieth century, the mysticism of death.

35 Ps 38,4-5.

36 A. Mickiewicz, Dziady, cz. II, https://wolnelektury.pl/media/book/pdf/dziady.pdf [dostęp: 27.01.2019].
\end{abstract}


Keywords: misticism; life; death; soul; God; language; Saint Teresa of Jesus; Giorgio Agamben

Słowa kluczowe: mistyka; życie; śmierć; dusza; Bóg; język; św. Teresa od Jezusa; Giorgio Agamben

\section{BIBLIOGRAFIA}

Agamben G., El lenguaje y la muerte. Un seminario sobre el lugar de la negatividad, thum. T. Segovia, Valencia 2003.

Agamben G., Idea prozy, thum. E. Górniak Morgan, Warszawa 2018.

Agamben G., Wspólnota która nadchodzi, thum. S. Królak, Warszawa 2008.

Biblia Tysiaclecia, http://biblia.deon.pl/ [dostęp: 27.09.2019].

Buber M., Opowieści chasydów, tłum. P. Hertz, Poznań 1986.

Heidegger M., Bycie i czas, thum. B. Baran, Warszawa 1994.

Heidegger M., Sein und Zeit, Tübingen 2006.

Lévinas E., Całość i nieskończoność: esej o zewnętrzności, thum. M. Kowalska, Warszawa 1998.

Mickiewicz A., Dziady, cz. II, https:/wolnelektury.pl/media/book/pdf/dziady.pdf [dostęp: 27.01.2019]

Pino Estivill E., La «cosa misma» del lenguaje en Giorgio Agamben. Una revisión del concepto de comunidad, „Romanica Olomucensia” Nr 26.1, 2014, file://C:/Users/Asus/AppData/Local/ Temp/Dialnet-LaCosaMismaDelLenguajeEnGiorgioAgambenUnaRevisionD-4872611.pdf [dostęp: 27.01.2019].

Teresa od Jezusa, Poezje. Poesías, tłum. M. Szafrańska-Brandt, Kraków 2015.

Teresa od Jezusa, Zamek wewnętrzny czyli Mieszkania, thum. D. Wandzioch, W. Ciak, Poznań 2009.

Jadwiga Clea Moreno-Szypowska - jest doktorantką Instytutu Badań Literackich (PAN). Obecnie jej zainteresowania skupiają się na poszukiwaniu literackich oraz filozoficznych aspektów mistycznych. 